İnceleme Makalesi - Review Article

\title{
Çalışma Hayatında Kadınlara Yönelik Sosyal Koruma ${ }^{1}$
}

\section{Social Protection for Women in Working Life}

\author{
Nalan ARKAN* \\ (i) 0000-0003-1592-7303 \\ Güven MURAT** \\ (iD) 0000-0003-2449-2532 \\ ÖZ
}

Kadınların çalışma hayatına katılımı, bireysel faydaların yanı sıra sürdürülebilir ekonomik büyüme ve sosyal kalkınma açısından da oldukça önem arz etmektedir. Ancak kadınlar, başta çalışma hayatı olmak üzere hemen her alanda birçok sorunla karşılaşmakta; firsatlara erişim, haklardan faydalanma, işe alınma ve yükselme gibi alanlarda ayrımcılığa maruz kalmaktadır. Bu noktada sosyal koruma kadınlar gibi dezavantajlı grupların sosyal dışlanmasını önlemede en önemli politika araçlarından biri olarak görülmekte; kadınlar açısından gerek toplumsal cinsiyet eşitliğinin gerekse firsat eşitliğinin sağlanması ve olumsuz koşulların iyileştirilmesi hususunda büyük önem taşımaktadır. Bu çalışma, sosyal korumayı detaylı biçimde ele alarak, bu kapsamda uygulanan programların çalışma hayatında yer alan kadınlar açısından önemini araştırmış ve programlara erişimde karşılaşılan engelleri belirleyerek bu engellerin giderilmesine yönelik çözüm önerileri sunmayı amaçlamıştır. Çalışma, betimsel bir araştırma olup ilgili alanda yayınlanan kaynaklar referans alınmıștır. Araştırma sonucunda, kadınların çalışma hayatında karşılaşmış oldukları sorunların temelinde cinsiyete dayalı ayrımcılığın olduğu, uygulanan program ve politikaların kadınların çalışma hayatındaki konumunu iyileştirmekle birlikte yine de toplumsal cinsiyet eşitliğinin tam olarak sağlanamadığ 1 ve kadın istihdamının istenilen düzeye erişemediği görülmüştür.

Anahtar Sözcükler: Çalışma hayatı, kadın işgücü, ayırımcilık, sosyal koruma
Sosyal Güvenlik Dergisi / Journal of Social Security

ilt: 11 Say1: 1 Y1l: 2021 /Volume: 11 Issue: 1 Year: 2021

Sayfa Aralığı: 175-194 / Pages: 175-194

OI: 10.32331/sgd.952575
The participation of women in working life is of great importance in terms of sustainable economic growth and social development, as well as individual benefits. However, women face many problems in almost every field, especially in working life, and are exposed to discrimination in areas such as access to opportunities, benefiting from rights, recruitment and promotion. At this point, social protection is seen as one of the most important policy tools in preventing the social exclusion of disadvantaged groups such as women, it is of great importance in terms of both gender equality and equality of opportunity and improvement of negative conditions. This study examines the importance of the programs implemented in this context for women in working life by examining social protection in detail, and aims to identify the barriers encountered in accessing the programs and offer solutions to eliminate these obstacles. The study is a descriptive research and references published in the related field are taken as reference. As a result of the research, it was found that gender based discrimination is the basis of the problems faced by women in working life; although the implemented programs and policies improved the position of women in working life, it was observed that gender equality could not be fully achieved and women's employment could not reach the desired level.

Önerilen atıf şekli: Arkan N. ve Murat G. (2021). Çalışma Hayatında Kadınlara Yönelik Sosyal Koruma. Sosyal Güvenlik Dergisi (Journal of Social Security). 11(1). 175-194

• Geliş Tarihi/Received: 05/04/2021 • Güncelleme Tarihi/Revised: 26/05/2021 • Kabul Tarihi/Accepted: 14/06/2021

\footnotetext{
${ }^{1}$ Bu makale Prof. Dr. Güven Murat'ın danışmanlığında Nalan Arkan tarafından hazırlanan “Çalışma Hayatında Kadınlara Yönelik Sosyal Koruma: Türkiye ile AB Ülkeleri Karşılaştırması” isimli yüksek lisans tezinden üretilmiştir

* Doktora Öğrencisi, Çanakkale Onsekiz Mart Üniversitesi, Lisansüstü Eğitim Enstitüsü, Çalışma Ekonomisi ve Endüstri İlişkileri Anabilim Dalı, nalanarkan@hotmail.com

** Prof. Dr., Karadeniz Teknik Üniversitesi, İktisadi ve İdari Bilimler Fakültesi,

Çalışma Ekonomisi ve Endüstri İlişkileri Bölümü, guvenmurat@ktu.edu.tr
} 


\section{GíRIŞ}

Kadınların çalışma hayatında yer alması ekonomik büyümenin sürdürülebilirliği ve sosyal kalkınmanın sağlanması hususunda şüphesiz önemli bir yere sahiptir. Kadınlar çalışma hayatına katılarak ekonomik özgürlüğün yanında özgüvenlerini geliştirmekte, sosyal statü sağlamakta ve toplumsal yaşamdaki konumlarını güçlendirerek saygınlıklarını artırmaktadır. Ancak toplumsal cinsiyete bağlı iş bölümü ve kadına yüklenen geleneksel roller, kadınların gerek sosyal hayatta gerekse çalışma hayatında birtakım sorunlarla ve eşitsizliklerle karşılaşmalarına neden olmaktadır. Kadınlar çalışma hayatında cinsiyete bağlı olarak işe alınma, yükselme, ücretlendirme ve karar alma gibi pek çok alanda ayrımcılığa maruz kalmakta ve erkeklere kıyasla birçok haktan daha düşük oranda faydalanmaktadır. Bu durum kadınları çalışma hayatının dışına itmekte ve uzun vadede sosyal güvenceden yararlanma firsatlarını azaltmaktadır. Dolayısıyla tüm bu olumsuz faktörler, kadınların daha kırılgan olmalarına ve sosyal koruma müdahalelerine daha fazla ihtiyaç duymalarına neden olmaktadir.

Sosyal koruma sistemi primlerle finanse edilen sosyal sigortalar ile vergilerle finanse edilen sosyal yardım ve hizmet uygulamalarının bir bütünü olarak bireylere pek çok alanda güvence sağlamaktadır. Sosyal korumanın özellikle, kadınların en çok maruz kaldığı cinsiyet eşitsizliğinin ve buna bağlı olarak ayrımcılığın önlenmesi, işgücü piyasasına katılımlarının sağlanması ve sosyal statülerinin artırılması gibi birçok alanda kadınların güçlendirilmesine katkı sağlayacağı öngörülmektedir. Bu anlamda atılan en önemli adımlardan biri Uluslararası Çalışma Örgütü (ILO)'nün kabul ettiği Sosyal Koruma Tabanları Tavsiye Kararı'dır. Bu Tavsiye Kararı, kapsamlı bir sosyal koruma sisteminin nasıl olması gerektiği konusunda geniş bir rehberlik sunmakla birlikte, insan onuruna yaraşır biçimde yaşayabilmek için gereken temel sosyal güvenlik garantilerini sunmayı ve evrensel bir korumayı hedeflemektedir. Bu bağlamda öncelikli olarak tüm kadınlara asgari bir gelir güvencesi ve temel hizmetlere erişim hakkının sağlanması temel amaç kabul edilmektedir.

Kadınların güçlendirilmesi, çalışma hayatına katılımının artırılması ve toplumsal cinsiyet eşitliğinin sağlanması gibi temel amaçlar için bu tür adımlar doğrultusunda uygulanan programlar/politikalar, şüphesiz kadınların çalışma hayatı ve toplumsal hayat içerisindeki konumunu iyileştirmekte ve kadın istihdamının artmasına katkı sağlamaktadır.

$\mathrm{Bu}$ çalışmada ilk önce sosyal korumanın kavramsal çerçevesi çizilerek sosyal koruma tabanları türleri ve sosyal korumanın refah üzerindeki etkilerinden bahsedilmektedir. Daha sonra, çalışan kadınlar için sosyal korumanın neden gerekli olduğu ve kadınlara yönelik sosyal koruma programları üzerinde durulmaktadır. Son olarak ise kadınların sosyal koruma tabanlarına erişim engelleri açıklanarak, kadınlara yönelik ulusal sosyal koruma tabanlarının güçlendirilmesine yönelik stratejilerden söz edilmektedir.

\section{I- SOSYAL KORUMA}

\section{A- Sosyal Koruma Kavramı ve Tanımı}

Sosyal koruma, bazı yazarlar tarafından sosyal güvenlik ile eşdeğer olarak görülmektedir. Sosyal güvenlik genellikle asgari düzeyde bir gelir güvencesi sağlayabilmek için insanların yararlanabileceği yardım, sigorta ve sosyal yardım programlarının tanımı olarak ifade edilmektedir. Dünya Bankası, sosyal koruma kavramını sosyal güvenceden ayrı olarak genişletmek için bir yol izlemektedir. Ancak hâlâ, işgücü piyasası müdahalelerinden kamuya zorunlu işsizlik veya yaşlılık sigortasından hedeflenmiş gelir desteğine kadar değişen, insan sermayesini korumak veya iyileştirmek için bir önlemler bütünü olarak sosyal korumayı araçsal olarak tanımlamayı sürdürmektedir (Wheeler ve Kabeer, 2005: 2). 
Birleşmiş Milletler (BM)'e göre sosyal koruma, gelir güvenliğini ve sağlık hizmetlerine erişimi güvence altına almak için nakit veya ayni fayda sağlayan tüm tedbirler olarak tanımlanmaktadır. Bu hususta kapsamlı sosyal koruma sistemleri hastalık, engellilik, analık, iş kazası, işsizlik, yaşlılık, aile üyelerinden birinin ölümü ile genel yoksulluk ve sosyal dışlanmanın neden olduğu işle ilgili gelir eksikliğine karşı koruma sağlamaktadır. Sosyal koruma ayrıca, temel sağlık hizmetlerine erişim ile özellikle çocuk ve yetişkin bağımlılar için aile desteği sağlamaktadır (UN, 2018: 5).

Sosyal koruma veya sosyal güvenlik, yaşam döngüsü boyunca yoksulluğu, kırılganlığı ve güvencesizliği azaltmak ve aynı zamanda önlemek için tasarlanmış politikalar ve programlar seti olarak tanımlanmaktadır (Murat, 2019: 38). Sosyal koruma dokuz temel alanı içermektedir. Bunlar; çocuk ve aile yardımları, analık koruması, işsizlik yardımı, iş kazaları yardımı, hastalık, sağlık koruması, yaşlılık, malullük ve dul ve yetim aylığıdır. Sosyal koruma sistemleri, primli (sosyal sigorta) ve primsiz vergiyle finanse edilen (sosyal yardımlar) uygulamaların bir karışımı olarak tüm bu alanlara hitap etmektedir (ILO, 2017a: 2).

Sosyal koruma her şeyden önce bir insan hakkıdır. Aktif işgücü piyasası ve formelleştirme politikalarını ilişkilendirmesi, toplumsal kapsayıcılığı ve cinsiyet eşitliğini teşvik etmesi, sosyal bütünlüğü ve siyasi istikrarı geliştirmesi, kriz ve şokların sosyal ve ekonomik etkilerini azaltması, insanların kapasitelerini ve verimliliklerini artırması, yoksulluğu ve hastalığı azaltması ve kapsamlı bir ekonomik büyümeyi teşvik etmesi gibi bir dizi fayda sağlamaktadır. Bu bağlamda sosyal koruma, sürdürülebilir kalkınma için kritik bir politika olarak görülmektedir (Aykaç ve Murat, 2018: 101).

Tüm bu tanımlardan hareketle sosyal korumanın tüm vatandaşları, özellikle dezavantajlı grupları kapsayan ve çok geniş bir yelpazede koruma sağlamayı amaçlayan ve sürdürülebilir ve kapsayıcı bir büyümenin temelini oluşturan bir niteliğe sahip olduğu görülmektedir.

\section{B- Sosyal Korumanın Kapsamı}

ILO Genel Konferans1, 2012 y1lında Cenevre'de toplanarak 202 no.lu Sosyal Koruma Tabanları Tavsiye Kararı'nı kabul etmiştir. Bu tavsiye kararı BM, G20 Ülkeleri, Güneydoğu Asya Ülkeleri Birliği ve Avrupa Birliği (AB) tarafından uygun bulunarak, küresel ve bölgesel düzeyde geniş onay almıştır. Sosyal koruma sistemlerinin yapısı ülkelere göre değişiklik göstermekle beraber, ILO'nun bu tavsiye kararı, kapsamlı bir sistemin temellerinin nasıl atılacağı konusunda kapsamlı rehberlik sunmaktadır (UN, 2018: 8).

Tavsiye Kararı'na göre üye ülkeler, ulusal koşullarına bağlı olarak temel sosyal güvenlik garantileri içeren sosyal koruma alanlarını mümkün olduğunca hızlı bir şekilde kurmalı ve sürdürmelidir. Bu garantiler asgari olarak, ihtiyaç duyan herkesin ulusal düzeyde zorunlu olarak tanımlanan ürün ve hizmetlere etkili erişimlerinin yanında, temel sağlık hizmetlerine ve temel gelir güvenliğine erişimini sağlamalıdır. Mevcut uluslararası yükümlülüklerine bağlı olarak üyeler, Tavsiye Kararı'nda belirtilen sosyal güvenlik garantilerini en azından tüm vatandaşlara ve çocuklara ulusal yasa ve yönetmeliklerde tanımlandığı gibi sağlamalıdır. Üye ülkelerin sosyal güvenlik garantilerini sağlarken, farklı yaklaşımları dikkate almaları gerekmektedir. Yardımlar, çocuk ve aile yardımları, hastalık ve sağlık-bakım yardımları, analık, malullük, yaşlılık, dul ve yetim aylığ 1 , işsizlik, istihdam garantileri ve iş kazası yardımlarının yanı sıra diğer ayni veya nakdi sosyal yardımları içerebilmektedir. Üye ülkeler ulusal sosyal koruma tabanlarını oluştururken ve uygularken önleyici, tanıtıcı ve aktif önlemleri, yardımları ve sosyal hizmetleri birleştirmeli; kamu alımı, devlet kredisi ve işgücü piyasası politikalarının yanı sıra eğitimi, üretim becerilerini ve istihdamı teşvik eden programları dikkate alarak üretken ekonomik faaliyeti ve kayıtlı istihdamı teşvik etmeli; mesleki eğitim ve istihdam edilebilirliği artıran, güvencesizliği azaltan ve sürdürülebilir 
işletmeleri teşvik eden diğer politikalarla koordinasyonu sağlamalıdır (Social Protection Floors Recommendation, 2012: No 202).

Tavsiye Kararı'na göre üye ülkeler sosyal devlet anlayışı doğrultusunda kendi sosyoekonomik koşullarına göre evrensel nitelikte bir sosyal koruma sistemi oluşturmalıdır. $\mathrm{Bu}$ sosyal koruma sistemleri sosyal sigorta, temel sağlık hizmetleri ve gelir güvenliğine erişime imkân tanımalıdır. Söz konusu Tavsiye Kararı sosyal koruma sistemi çerçevesinde bir taraftan ihtiyaç sahibi vatandaşlara sosyal güvence sağlarken, diğer taraftan aktif iş gücü piyasası politikaları ve diğer politikalar aracılığıyla bireylerin istihdam edilebilirliğini artırmalı, güvencesizliğini azaltmalı ve işletmelerin sürdürülebilirliğini sağlamalıdır.

\section{C- Sosyal Koruma Tabanları Türleri}

Sosyal koruma tabanları; sosyal sigortalar, sosyal yardımlar, işgücü piyasası müdahaleleri, geleneksel veya informel sosyal koruma ve diğer sosyal koruma türlerinden oluşmaktadır.

\section{i) Sosyal Sigortalar}

Katılımcıların hastalık, sakatlık, analık, işsizlik, yaşlılık veya ölüm gibi yaşam boyu devam eden olaylarla ilgili masrafları karşılayacak bir sigorta programına düzenli olarak ödeme yaptıkları programlardır. Sosyal sigorta sistemlerinin mevcut durumu ve programların kapsamı bölgeye ve ülkeye göre değişiklik göstermektedir (Holmes ve Scott, 2016: 13). Sosyal sigorta programlarında maliyetler bazen program sağlayıcı tarafından karşılanmakta veya sübvanse edilmektedir. Bu programlar; emekli maaşları, sağlık, işsizlik veya afet sigortaları ile cenaze yardımlarını içermektedir (Arnold, Convey ve Greenslade, 2011: 91; Browne, 2015: 6). Sosyal sigorta, formel işgücü piyasasıyla güçlü bir şekilde bağlantılıdır ve tipik olarak sadece formel sektör çalışanlarını kapsamaktadır (Holmes ve Scott, 2016: 9). Bu bakımdan, formel sektör dışında kalan çalışma hayatındaki diğer tüm bireyler bu koruma kapsamının dışında kalmaktadır.

\section{ii) Sosyal Yardımlar}

Yoksulluğu ve kırılganlığg azaltmak için hanehalklarına ve bireylere yönelik, gelirleri artıran doğrudan, düzenli ve primsiz sosyal transferlerdir. Bu transferler nakit veya ayni yardım şeklinde olabileceği gibi kuponlar veya mal ve hizmetlere ücretsiz ya da indirimli erişim şeklinde de yapılabilmektedir. Sosyal yardım, evrensel bir hak olarak sağlanabilmekte veya yoksulluk ve diğer kriterlere göre bağlanabilmektedir (Arnold, Convey ve Greenslade, 2011: 91). Bu yardımlar genellikle devlet tarafından sağlanmakta ve ulusal vergilerle finanse edilmektedir. Sosyal yardımların bazıları dezavantajlı grupları, bazıları da genellikle düşük gelirli grupları hedef almaktadır. Bu, birçok gelişen ülkede uygulanan mevcut sosyal koruma biçimi olarak görülmektedir. Sosyal yardımlar kendi içinde nakit ve ayni transferler, sosyal emeklilik maaşları ve kamu istihdam programları olarak alt gruplara ayrılmaktadır (Browne, 2015: 6-7).

\section{iii) İşgücü Piyasası Müdahaleleri}

$\mathrm{Bu}$ müdahaleler aktif veya pasif olabilmektedir. Aktif müdahaleler, işsizlerin ve en dezavantajlı kişilerin iş bulmalarına yardımcı olurken; pasif müdahaleler, halihazırda çalışanlar için işveren tarafından finanse edilen analık, iş kazası ve hastalık yardımlarını kapsamaktadır (Browne, 2015: 7). Bu programlar, bir yandan kamu işlerinde istihdama yasal bir hak tanıma ve dezavantajlı veya kırsal kesimdeki yoksul işçiler için nakit transferleri sağlayan istihdam garantisi programı biçimini alırken, öte yandan işsizlerin yanı sıra güvencesiz istihdamdaki işçilerin istihdam edilebilirliğini artırmayı amaçlayan beceri geliştirme ve eğitim programı şeklinde karşımıza çıkabilmektedir. İşgücü piyasası 
müdahalelerinin amacı, bireyleri korumak ve onların işgücü piyasasına dahil olmalarına katkı sağlamaktır. Dolayısıyla bu programlar sosyal korumanın vazgeçilmez bir parçasıdır ve işsizlerin iş bulma ihtimalini veya işsizlerin verimliliklerini ve kazançlarını artırma imkanını yükseltmektedir (ESCAP, 2015: 78-79).

\section{iv) Geleneksel veya İnformel Sosyal Koruma}

Formel sosyal koruma sistemleri tam bir kapsama alanı sunmamakta ve nüfusun bir kısmını kaçınılmaz olarak dışlamaktadır. Geleneksel toplum temelli sosyal koruma biçimleri bir toplum içindeki riski dağıtmakta ve resmi müdahaleler tarafından bırakılan bazı boşlukları doldurmaktadır (Browne, 2015: 7). Bu yardımlar doğrudan devlet desteği olmadan akraba, topluluk, dini kuruluşlar vb. birtakım devlet dışı kaynak tarafından yapılan transferlere dayanmakta ve karşılıklı destek ve dayanışma doğrultusunda gerçekleşmektedir (Norton, Convay ve Foster, 2001: 11).

\section{v) Diğer Sosyal Koruma Türleri}

Sosyal bakım ve destek, sosyal korumayı tamamlayıcı niteliktedir. Devlet ve özel sektör sübvansiyonları, yoksullar için erişim sağladığı veya güvenlik ağı görevi görmeleri durumunda, sosyal koruma olarak sınıflandırılabilmektedir (Browne, 2015: 7).

Yukarıda sıralanan sosyal koruma programları birbirlerini ikame edici değil tamamlayıcı niteliktedir. Örneğin sosyal sigorta kapsamına girmeyen kesimlere sosyal yardım ve geleneksel veya informel sosyal koruma uygulamalarıyla sosyal koruma sağlanmaya çalışılmaktadır. İşgücü piyasası müdahaleleri de çalışabilen ancak sosyal korumadan yeterince faydalanamayanlara asgari düzeyde bir koruma sağlamaya yönelik olarak gerçekleştirilmektedir.

\section{II- ÇALIŞAN KADINLARA YÖNELIKK SOSYAL KORUMA}

Ekonomik olarak aktif olsun veya olmasın çalışma çağındaki herkesin özel sosyal korumaya ihtiyacı vardır. $\mathrm{Bu}$ ihtiyacı karşılamaya yönelik etkili politikalar sadece sosyal güvenlik hakkının gerçekleştirilmesinde değil, işgücü piyasalarının etkin bir şekilde işleyişinde ve daha geniş ekonomik ve sosyal kalkınmanın sağlanmasında da kilit bir rol oynamaktadır (ILO, 2017a: 24). Bu başlık altında, çalışan kadınlar için sosyal korumanın gerekliliği ve çalışan kadınlara yönelik sosyal koruma programları ele alınmaktadır.

\section{A- Çalışan Kadınlar için Sosyal Korumanın Gerekliliği}

Kadınlar ve kız çocukları, kaynaklara erişim, temel hizmetler ve karar alma dahil olmak üzere yaşamın birçok alanında ayrımcılığa maruz kalmaktadır. Kadınlar sermaye yetersizliği, yüksek ücret farklılıkları ve cinsiyetçi çalışma normları ile temel hizmetlerden dışlanmalarından dolayı orantısız bir şekilde savunmasız oldukları için sosyal korumaya daha fazla ihtiyaç duymaktadır. Sosyal koruma cinsiyet eşitliğinin sağlanması, kadınların işgücüne katılımının artırılması, aile içi şiddetin azaltılması ve ücretsiz bakım hizmetlerinin yeniden dağıtılmasını destekleme gibi çeşitli biçimlerde kadınların güçlendirilmesine katkıda bulunabilmektedir. Nakit transferleri ulaştırma, giyim ve çocuk bakımı da dahil işe erişimle ilgili maliyetleri karşılayarak veya kadınların sağlığını iyileştirerek işgücüne katılmalarını sağlayabilir. Sosyal yardım programları özellikle koşullu nakit transferleri, transfer alıcısı ve fonların yöneticisi olarak genellikle kadınları hedeflemektedir (Browne, 2015: 30; ESCAP, 2018: 7).

Kadınlar, sosyal güvenlik hakkı dahil, haklardan yararlanma konusunda erkeklerden daha fazla engelle karşılaşmaktadır. Karşılaşılan ekonomik, politik ve eğitime ilişkin dezavantajlar, kendilerine sunulan haklara ve bu hakların kapsamına etki etmektedir. İşgücü 
piyasasında kadınlar ve erkekler arasındaki kalıcı eşitsizlikler, sosyal koruma kapsamında cinsiyet farklılıklarını etkilemektedir. Birçok ülkede işgücüne katılım, kadınlar arasında erkeklere oranla daha düşüktür. Kadınlar informel istihdamda daha fazla temsil edilmektedir. Tam zamanlı çalışmalarda ise kadınlar ortalama olarak erkeklerden $\% 10$ ile $\% 30$ daha az kazanmaktadır. Ayrıca kadınlar, ücretsiz bakım çalışmaları nedeniyle erkeklerden daha fazla sorumluluk yüklenmektedir. Bu durum, kadınların kayıtlı istihdam ve eğitime katılmak, siyasi faaliyetlerde bulunmak veya sadece boş vakitleri değerlendirmek hususunda erkeklere kıyasla çok daha az zamana sahip olmalarına neden olmaktadır (UN, 2018: 18).

İşyerinde kadınların geleceği, kadın ve erkeklerin yaşamları boyunca sosyal korumaya ne ölçüde etkili bir şekilde erişim sağlayabildiklerine bağlı olacaktır. Sosyal koruma tabanlarıyla birlikte toplumsal cinsiyete duyarlı sosyal koruma sistemleri, toplumsal cinsiyet eşitliğini ve gelecekte kadınların güçlenmesini teşvik etmenin anahtarı olarak görülmektedir (ILO, 2019a: 84).

Sosyal sigorta programları, kadın ve erkeklerin karşılaştığı farklı yoksulluk ve kırılganlık deneyimlerini dikkate alarak nadiren tasarlanmakta ve uygulanmaktadır. Bu yalnızca sosyal sigorta programlarında kadınların daha az kapsanması değil, faydaların da kadınların karşılaştıkları risklere karşı yeterince koruma sağlayamaması anlamına gelmektedir. Koordineli bir sosyal yardım paketi, sosyal sigorta, işgücü piyasası ve bakım programları bireylerin ve ailelerinin yoksulluk içine düşmelerini engelleyebilmekte, temel hizmetlere erişimi teşvik edebilmekte, işgücü verimliliğini artırarak ekonomik büyümeye katkıda bulunabilmekte ve sosyal ilişkileri güçlendirebilmektedir (Holmes ve Scott, 2016: 1, 10).

\section{B- Çalışan Kadınlar için Sosyal Koruma Programları}

\section{i) İşsizlik Sigortası}

İşsizlik sigortasının amacı, faydalanıcıya uygun bir istihdam firsatı sunana kadar belli bir yaşam standardını sürdürebilmesi ve geçici işsizlikten kaynaklanan kazanç kaybını giderebilmesi için asgari bir gelir garantisi sağlamaktır. Ayrıca bu programlar bireylere iş bulma konusunda destek, danışmanlık, beceri geliştirme ve girişimcilik gibi bir dizi hizmet sunarak, istihdam edilebilirliklerini artırmakta ve üretken istihdama geçişlerini kolaylaştırmaktadır. Böylece işsizliğe karşı koruma programları, gelir güvencesi sağlamasının yanı sıra, iş kaybı etkisini hafifleterek hanehalkının savunmasızlığını etkili bir şekilde azaltabilmekte, yoksulluğun önlenmesine ve bireylerin kayıt dışılığa karşı korunmalarını sağlayabilmektedir. Dolayısıyla, bu programlar iş hareketliliğini desteklemede ve ekonominin yapısal değişimini kolaylaştırmada kilit bir rol oynamaktadır (https:// socialprotection-humanrights.org/key-issues/social-protectionsystems/unemployment-protection/). İşsizliğe karşı koruma programlarının hem gelir güvencesi sağlanmasına hem de istihdama geçişin kolaylaştırılmasına yönelik bu çift yönlü hedefi, ILO'nun 168 no.lu İstihdamın Korunması ve İşsizliğe Karşı Koruma Sözleşmesi’nin de merkezinde yer almaktadır. İşsizliğe karşı koruma programları, kazanç kaybına ikame gelir etkisi sağlamakta ve gelir kaybının olumsuz etkisini hafifletmektedir. Ayrıca, bireylere işsiz kaldıklarında yoksulluktan korunmalarını sağlamada temel bir rol oynamaktadır. (ILO, 2017a: 40-42).

İşsizliğe karşı koruma, farklı türlerdeki programlar aracılığıyla yapılmaktadır. Temel işsizlik koruma programları primli ve primsiz işsizlik yardım programı, istihdam garantili programlar ve bireysel işsizlik tasarruf programları şeklinde uygulanmaktadır (ILO, 2017a: 44-46). OECD (Ekonomik İşbirliği ve Kalkınma Örgütü) ülkeleri de dahil dünya genelinde yaklaşık 72 ülke, kadın ve erkek işsizlerin finansal olarak desteklenmesi amacıyla tasarlanmış bir işsizlik sigortası sistemine sahiptir. Genel olarak tipik bir işsizlik sigortası sistemi kayıtlı istihdamdaki tüm ücretli işçileri koruyan, ulusal veya yerel düzeyde yürütülen zorunlu bir sigorta sistemidir. Programdan yararlanabilmek için genellikle bireylerin belirli bir süre 
çalışmış olması ve işten ayrılma nedeni gibi iki tür uygunluk kriteri aranmaktadır. Faydalanıcıların işten ayrılmadan önceki çalışma süresi ve hak kazanması durumunda ödenecek ücretin miktarı ve ödeme süresi ülkelere göre farklılaşmaktadır. Programın finansmanı ise genellikle işçi ve işverenden alınan katkılar aracılığıyla karşılanmaktadır. Katkı oranları genellikle brüt kazancın yüzdesi olarak, $\% 1$ ile $\% 3$ arasında değișmektedir ve çoğunlukla işçi-işveren arasında eşit olarak bölünmektedir (Schmieder ve Wachter, 2016: 24).

ILO tarafından yayımlanan Dünya Sosyal Koruma Raporu'nda (2017-19) mevcut verilerin bulunduğu 203 ülkenin 98'inde ulusal yasa kapsamında bir işsizlik yardım programı bulunmaktadır. Bu ülkelerin 92'sinde, hak sahibi işsizlere düzenli nakit yardımları sağlanmaktadır. Rapora göre, dünya genelinde işgücünün sadece \%38,6'sı işsizliğe karş1 koruma yardımları ile yasal çerçevede korunmaktadır. Bunun en büyük nedeni, informel istihdamın oldukça yüksek düzeyde olması ve işsizliğe karşı koruma programlarının eksikliği olarak gösterilmektedir. Aynı rapora göre, dünyadaki işsizlerin sadece \%21,8'i işsizlik yardımı alıyorken, geriye kalan \%78,2'lik kesim, gelir desteği almada kapsam dışı kalmıştır (ILO, 2017a: 46-48).

Kadınlar açısından değerlendirmek gerekirse, kadınların erkeklere kıyasla hem işgücüne katılma olasılığı daha düşük hem de katıldıklarında da işsiz kalma olasılığı çok daha yüksektir. ILO'ya göre, küresel düzeyde kadınların işsizlik oranı 2017'de \%6,2 olup, \%5,5 olan erkek işsizlik oranından 0,7 puanlık bir farkı temsil etmektedir. Bu farkın 2021'e kadar nispeten değişmeyeceği öngörülmekte ve gelişmekte olan ülkelerde ise farkın daha da genişlediği belirtilmektedir (ILO, 2017b: 8). Dolayısıyla işsizlik sigortası, işsiz kalan kadınlara belirli bir düzeyde gelir güvencesi sağlamasının yanında, sunduğu hizmetlerle beşerî sermayesini geliştirebilmesi ve işgücüne katılımını teşvik edebilmesi bakımından önemli görülmektedir. Öte yandan, kadınların büyük bölümünün informel sektörde güvencesiz işlerde istidam edildiği dikkate alınırsa, erkeklere kıyasla işsizlik sigortasından daha az faydalandığı söylenebilir.

\section{ii) Analık Koruması}

Hamilelik ve analık durumları, birçok kadın için iş güvencesizliğine neden olmaktadır. Dünya çapında istihdam edilen kadınların büyük çoğunluğu hala analık durumunda gelir kaybına karşı korunmamaktadır. İstihdamdaki kadınların yalnızca \%45'i zorunlu yasal analık korumasından faydalanmaktadır. İşverenler, doğum ve çocuk bakımı nedeniyle ortaya çıkabilecek iş kaybı ve analıkla ilgili maliyetlerden kaçınmak amacıyla genellikle hamileleri ve çocuk doğurabilecek yaştaki kadınları işe almada gönülsüz davranmaktadır. Dolayısıyla kadınlar için analık hali, istihdam edilebilme ihtimallerini azaltırken ayrıca gelir kaybı yaşamalarına neden olmaktadır (ILO, 2017a: 31; Cameron, 2019: 4). Bu durum kadınların üretkenliğini baltalamakla birlikte, yaşanan gelir şoklarına karşı savunmasızlıklarını artırmakta ve yaşlılık için birikim yapmalarını zorlaştırmaktadır (Cameron, 2019: 9). Dolayısıyla sosyal koruma programlarının kadınların sosyal durumu ve ihtiyaçları doğrultusunda özel olarak tasarlanması, sağlanan güvencenin kapsayıcılığının ve erişiminin artırılması önem arz etmektedir.

Analık koruması, yoksulluk ve savunmasızlığı önlemek veya azaltmak, annelerin ve çocukların sağlığını, beslenmesini ve refahını artırmak, işyerinde cinsiyet eşitliğini sağlamak ve hem kadınlar hem de erkekler için insan onuruna yaraşır işler geliştirmek hususunda, 2030 Sürdürülebilir Kalkınma Hedefleri'nde (SKH) öngörülen dönüşüm politikalarının önemli bir bileşenidir. Analık koruması 1, 2, 3, 4, 5 ve 8 . hedefler dahil olmak üzere birden fazla SKH'nin gerçekleştirilmesinde esas kabul edilmektedir. Ayrıca, hamile kadınlar, yeni doğum yapmış anneler ve aileleri için gelir güvencesi sağladığı gibi anne ve çocuk sağlık bakım 
hizmetlerinin daha kaliteli olmasını ve bu hizmetlere etkili erişimlerini kapsamaktadır. İstihdamda ve meslekte eşitliği teşvik etmektedir. Analık koruması, yalnızca gelir güvenliği ve sağlık bakımını kapsamamakta, aynı zamanda çalışma faaliyetlerini durdurma, doğum sürecinde dinlenme ve iyileşme hakkını da içermektedir. Bu koruma, analık süresince ve sonrasında işyerinde kadınların haklarını koruma, riskleri önleyen önlemler alma, sağlıksız ve güvenli olmayan çalışma koşulları ve ortamlardan koruma, istihdamı güvence altına alma, ayrımcılığa ve işten çıkarılmaya karşı koruma ve doğum sonrası işlerine geri dönmelerini sağlama şeklinde çeşitli korumalar sağlamaktadır (ILO, 2017a: 27-28).

Analık nakit yardımları, ulusal sosyal güvenlik mevzuatına bağlı olarak sosyal sigortalar, sosyal yardımlar veya işverenin sağladığı haklar aracılığıyla yürütülmektedir. Bu programların oldukça önemli bir kısmını ise sosyal sigorta programları oluşturmaktadır. Sigorta primleri, vergiler veya her ikisiyle finansmanı sağlanan toplu finanse edilen programlar, dayanışma ve risk havuzu ilkelerine dayalıdır ve bu nedenle yeniden üretim maliyetlerinin ve sorumluluğunun daha adilce dağıtılmasını sağlamaktadır. Ancak analık yardımları da işsizlik sigortasında olduğu gibi yalnızca kayıtlı istihdamdaki kadınlara yönelik koruma sağlamaktadır. Dolayısıyla kayıtlı istihdam düzeylerinin düşük olduğu birçok düşük ve orta gelirli ülkede analık yardımları sadece azınlıktaki bir gruba fayda sağlamaktadır (ILO, 2015: 3-4).

Dünya Sosyal Koruma Raporu’na (2017-19) göre, 199 ülkeden 99'u kadınların doğum sonrası tamamen iyileşebilmeleri için ILO'nun 183 no.lu Analık Koruması Sözleşmesi standartlarına uygun olarak en az 14 haftalık analık izni sağlamaktadır. Bu ülkelerden 37'si 18-26 hafta arası izin sağlarken, 11 'inde izin 26 haftadan daha fazla sürmektedir. 49 ülkede ücretli analık izin süresi 12-13 haftadır. 30 ülkede ise nakit yardımlarla birlikte analık izni 12 haftadan daha az sürmektedir. Aynı rapora göre, analık nakit yardımının düzeyi ülkeden ülkeye değişiklik göstermekte olup, 192 ülkeden 73'ünde kadınlara, en az 14 hafta süreyle düzenli maaşlarının en az 2/3'ü kadar ücretli analık izni hakkı verilmektedir. 26 ülkede kadınlar, en az 18 hafta süre için düzenli maaşlarının tamamını alma hakkına sahiptir. 6 ülkede ise kadınlara asgari ücret gibi sabit düzeyde bir yardım sağlanmaktadır (ILO, 2017a: 33). Bu rakamlar küresel ölçekte tüm ülkelerin yaklaşık yarısının çalışan kadınlara analık koruması sağlarken, diğer yarısında kadınların bu korumadan yoksun olarak çalıştığını ortaya koymaktadır.

\section{iii) Sağlık Sigortası}

Toplumsal cinsiyet perspektifleri, biyolojik ve sosyal faktörlere bağlı olarak kadınların ve erkeklerin farklı sağlık profiline sahip olmalarından dolayı, sağlık hizmetleri politikalarının tasarlanmasında önemlidir. Kadınlar genellikle genetik faktörler nedeniyle erkeklerden daha uzun yaşamakta ve aynı zamanda farklı davranış, yaşam tarzı ve çalışma biçimine sahip bulunmaktadır. Kadınlar cinsiyete özgü hastalıklar, üreme ve sosyoekonomik kaygılar (yeme bozukluğu, kadına karşı şiddet, işe bağlı stres vb.) gibi durumlar karşısında özel sağlık hizmetlerine ihtiyaç duymaktadır. Öte yandan kadınlar hastalık nedeniyle azalan iş kapasitesine ve strese bağlı zihinsel bozukluklara erkeklere oranla daha fazla eğilimlidir. Bu bağlamda, etkili, erişilebilir ve kaliteli bir sağlık hizmetinin sunulabilmesi için ülkelerin kadın ve erkeklerin fiziksel farklılıklarına ve aynı zamanda sosyoekonomik faktörlere bağlı bir toplumsal cinsiyet perspektifi benimsemeleri, sağlık hizmetlerinin maliyetinin azaltılması ve cinsiyet temelinde maliyetlendirilmesi en önemli sosyal önceliklerden biri olarak kabul edilmektedir (OECD, 2008: 49-51).

Sağlık hizmetleri genellikle kırsal alanlarda daha sınırlıdır ve sosyokültürel farklılıklar çoğu zaman erişime engel oluşturmaktadır. Uygun fiyatlı sağlık hizmetlerine erişimin yetersizliği, eşitsizlik tuzaklarının yaratılmasına veya sürekli hale gelmesine neden olmaktadır. Sağlık 
hakk1, İnsan Hakları Evrensel Beyannamesi'nin 25. maddesinde ve BM Ekonomik, Sosyal ve Kültürel Haklar Sözleşmesi'nin 12. maddesinde yer almaktadır. Bu normatif çerçevede bulunan 202 no.lu Tavsiye Kararı, analık koruması da dahil olmak üzere temel sağlık hizmetini teşkil eden uluslararası tanımlanmış bir dizi ürün ve hizmete erişimi garanti etmektedir. Bu ürün ve hizmetlerde kullanılabilirlik, erișilebilirlik, kabul edilebilirlik ve kalite kriterleri esas alınmaktadır. Sağlığa yapılan yatırımlar, hanehalkı düzeyinde ekonomik güvenliği, ulusal düzeyde ise sosyal uyum ve iş odaklı büyümeyi teşvik etmektedir. Ayrıca herkes için uygun ve erişilebilir sağlık hizmeti sağlayarak kapsayıcı ve sürdürülebilir kalkınmayı da teşvik etmektedir. Daha sağlıklı bir nüfus içerisinde yaşayan insanlar, çalışma hayatında daha üretken olmakta, hastalık halinde iyileşmek için daha az zaman harcamakta ve hasta bağımlılarına bakmak durumunda olan bireyler de bu süreç için daha az zaman kullanmaktadır. Bu bağlamda evrensel/genel sağlık koruması, hak temelli bir bakış açısının yanında ekonomik ve sosyal fayda sağlamasından dolayı zorunlu görülmektedir (ESCAP, 2015: 99,104).

Bir ülkede kapsamlı bir yasal sağlık sigortasının bulunması, yeterli fon kaynağının olması ve kaliteli bir hizmet sunabilmek için iyi çalışma koşullarına sahip yeterli düzeyde sağlık çalışanlarının tedarik edilmesi, ölüm oranlarının azalmasında ve nüfusun sağlık durumunun artmasında önemli bir potansiyele sahiptir. Yeterli düzeyde nitelikli sağlık çalışanlarının olmaması durumunda, yaşam boyu bakım işinin büyük bölümü gönüllüler tarafından sağlanmaktadır. Küresel olarak yaklaşık 57 milyon ücretsiz bakım işçisinin olduğu tahmin edilmekte ve bu işçilerin oldukça büyük kısmını ise aile üyelerinin bakımını sağlamak için mesleklerinden ve sosyal korunmadan vazgeçmiş, ücretsiz ve kayıt dışı çalışan kadınlar oluşturmaktadır. Dolayısıyla küresel olarak uzun vadeli bakım hizmetini yerine getirecek olan işgücü eksikliğinin giderilmesi, hem öncelikli olarak gerek duyulan kaliteli sağlık hizmetlerine erişimi sağlayacak hem de ücretsiz işlerin uygun ve verimli işlere dönüşümünü destekleyecektir. Böylece, evrensel bir sağlık korumasının sağlanması da sağlık çalışanları için yüksek üretkenliğe ve uygun işlerin yaratılmasına dayalı kapsayıcı ekonomik büyümeye de katkı sağlayacaktır (ILO, 2017a: 102).

\section{iv) Hayat ve Maluliyet Sigortası}

Çalışma çağındaki engelli kadın ve erkekler genellikle yüksek oranda işsizlik, eksik istihdam ve kayıt dışı istihdam riski ile karşılaşmaktadır. Bu riskler, engelli kadın ve erkek bireylerin hem iyi işlere erişimlerini hem de düzenli kazanç elde etmelerini ve bağımsız yaşama kapasitelerini oldukça kısıtlamaktadır. Bu bağlamda maluliyet yardımları, özellikle gelir güvenliğinin sağlanmasının yanında çocuk bakımı ve yardımcı aletlerin tedarik edilmesi gibi destek hizmetleri ile eğitim, sağlık ve toplu taşıma gibi sosyal hizmetlere erişimi kolaylaştırmada ve istihdamı teşvik etmede önemli bir rol oynamaktadır (ILO, 2017a: 6668).

Engelli kadın veya kız çocukları, engelli erkeklere kıyasla daha dezavantajlı konumdadır. Özellikle cinsiyete dayalı ayrımcılığa daha fazla maruz kalmaktadır. Kız çocukları ve engelli genç kadınlara yönelik cinsiyet ayrımcılığı çok erken yaşlarda başlamaktadır. Engelli kızların evde bakım ve gıdaya erişim ihtimalleri daha düşüktür (UNFPA, 2018: 24). Örneğin, normal bir kadın, engelli bir çocuğa sahip olması durumunda, çocuğun ihtiyaçlarını karşılama ve ebeveynlik için gerekli mali yardımı alacaktır. Ancak engelli bir kadın veya anne, böyle bir durum karşısında istese bile özel bir yardım alamayacağı gibi bir de ebeveyn olmayı seçtiği için eleştirilme riskiyle karşılaşacaktır (Beleza, 2003: 45). Aynı zamanda bunların aile içi etkileşimlerin ve etkinliklerin dışında kalma ihtimalleri de daha yüksektir. Öte yandan engelli kız çocukları veya kadınların sağlık hizmetlerine erişimi veya yardımcı cihazları alma ihtimali erkeklere oranla daha düşük olmakla birlikte eğitim veya iş bulabilmeleri için 
gereken mesleki eğitimi alma ihtimali daha da düşüktür. Dolayısıyla engelli kadınların yoksulluk içinde yaşama olasılığı yüksek olup, cinsiyete dayalı şiddete daha fazla maruz birakılmaktadır (UNFPA, 2018: 24).

Maluliyet yardımları, engellilikle ilgili ihtiyaçları açıkça ele alan ve engellilere ve ailelerine gelir desteği sağlayan sosyal koruma sistemlerinin unsurlarından biridir. Bu yardımlar engelli bireylerin işgücü piyasasına yeniden entegrasyonunu desteklemesi, istihdama katılımlarını kolaylaştırması ve bağımsız yaşam ve gelir güvenliğinin sağlanması bakımından önemli rol oynamaktadır. Söz konusu yardımlar engellilik maaşı gibi primli ya da primsiz programlar aracılığıyla yapılmaktadır (https://socialprotection-humanrights.org/key-issues/socialprotection-systems/disability-benefits/). Maluliyet yardım programları, kişilerin ihtiyaçları ve gereksinimleri doğrultusunda kısa veya uzun vadede nakit veya ayni olarak yardım sağlamaktadır. Bu kapsamda birçok ülkede ücretsiz ve engellilerin kullanımına uygun olarak tasarlanmış toplu taşıma, kamu hizmetlerine ücretsiz erişim ile yardım cihazlarının ücretsiz veya devlet desteğiyle sağlanması gibi birleştirilmiş nakdi ve ayni yardım paketleri uygulanmaktadır. İhtiyaç sahibi kişilerin elde ettiği bu kazançlar, gelir güvenliğini garanti altına alma potansiyeli olan parasal değere sahip ayni yardımlardır (ILO, 2017a: 68).

Nakit yardımlardan biri olan Sosyal Güvenlik Maluliyet Sigortası ise büyük ölçüde çalışma yeteneğini olumsuz yönde etkileyen sağlık problemlerine karşı sigortalı kişileri veya eşlerini ve onlara bağımlı kişileri korumak amacıyla uygulanan bir sigorta programıdır. Programın uygulanabilmesi için bazı koşulların yerine getirilmesi gerekmektedir (Low ve Pistaferri, 2010: 9). Bu koşullar, ülkelerin benimsemiş oldukları sosyal güvenlik sistemi kapsamında ülkelerin sosyokültürel yapı ve ekonomik koşullarına göre farklılık göstermektedir.

\section{v) Emeklilik Planları}

Bireylere yaşlılık dönemlerinde bir gelir güvencesinin sağlanması, modern toplumların gerçekleştirmek istediği temel refah hedeflerinden birisidir. Çünkü çalışma yaşamı süresince sağlı̆̆ 1 ve üretim kapasitesi iyi durumda olan ve üretken kapasitesinden yararlanan bireylerin, aynı zamanda ulusal kalkınmaya ve ilerlemeye katkı sağladığı düşünülmektedir. Dolayısıyla insanların yaşlılık dönemlerinde de bu kapasiteden geride kalmamaları ve refahın onlarla paylaşılması için yaşlı kadın ve erkek bireylerin savunmasızlık riskine karşı sistematik bir koruma sağlayan güvenilir mekanizmalara ihtiyaç duyulmaktadır. Bazı nüfus grupları kişisel tasarruflar gibi kendi bireysel çabalarıyla bu koruma mekanizmalarına erişebilirken, diğerleri aile destek mekanizmalarından yararlansalar bile çalışma yaşamı süresince gelir kaynaklarının güvenilir olmaması ile yüzleşmektedir. Birçok ülkede ekonomik kalkınmanın yapısal problemleriyle ilişkili olan kayıt dışılığın bir sonucu olarak, dünya genelinde yalnızca küçük bir kısım yaşlılık döneminde kendini koruyabilecek kapasiteye sahiptir. Bu nedenle sosyal koruma sistemleri yaşlı kadın ve erkek bireyler için çok önemli bir role sahiptir (ILO, 2017a: 76).

Emekli aylıkları, yaşı kadın ve erkeklere yönelik dünyada en yaygın uygulanan sosyal koruma biçimlerinden biridir. Küresel düzeyde, yaşlı insanların \%68'i emekli aylığı almaktadır ve bu anlamda son yıllarda önemli bir ilerleme kaydedilmekle beraber bölgesel olarak farklılıklar gözlenmektedir. Örneğin, Amerika, Avrupa ve Orta Asya geniş ölçüde evrensel bir koruma sağlarken, Sahra Altı Afrika, Güney Asya ve Arap ülkelerinde yaşlı insanların yalnızca \%30'undan daha azı emekli aylığı alabilmektedir (Ortiz ve Juergens, 2019: 28).

Emeklilik koruması, kadın bireyler açısından ayrı bir önem taşımaktadır. Toplumsal cinsiyete dayalı eşitsizliğin bir sonucu olarak kadın-erkek arasındaki ücret farkları, özellikle kadınlar için daha büyük bir emeklilik farkına neden olmaktadır. Dolayısıyla erkeklere kıyasla 
kadınların emeklilik aylığı alma ihtimali daha düşüktür ve alınsa dahi daha düşük oranlıdır. Aynı zamanda bu durum, kadınların emeklilik programının sağladığı faydalardan da daha az yararlanması anlamına gelmektedir. $\mathrm{Bu}$ bağlamda, eşit işe eşit ücret uygulamasının sağlanabilmesi ve kadınlar ile erkeklerin emeklilik haklarını kazanmaları için eşit firsatların sağlanması, emekli maaşlarının uzun vadeli yeterliliği bakımından ve özellikle kadınlar açısından oldukça önemlidir. $\mathrm{Bu}$ durumun cinsiyete dayalı emeklilik farklarının azaltılmasında da kayda değer bir olumlu etkisi olacaktır (ILO, 2019a: 70,82; Ortiz ve Juergens, 2019: 28).

Kadınlar emekli maaşlarını erkeklere kıyasla erken yaşta almaktadır. Aynı zamanda kadınlar erkeklerden 3-5 yıl daha uzun yaşama eğilimindedir. Kadınların ortalama emeklilik gelirinin erkeklere oranla daha düşük olması, yaşlı kadınların erkeklerden daha yüksek bir yoksulluk riskine sahip olmasına neden olmaktadır. Örneğin AB ülkelerinde emekli aylıklarındaki cinsiyet farkının üye devletlerde \%1,8 ile \%48,7 arasında değiştiği, buna karşılık AB-28'de ise 65-79 yaşlarındaki emekliler için \%37,2 civarında olduğu görülmektedir (European Commission, 2018: 68-69).

Dolayısıyla toplumsal cinsiyet eşitliğinin sağlanması her alanda olduğu gibi kadınlara uzun vadeli bir güvence sağlayacak olan emeklilik koruması açısından da oldukça önem arz etmekte ve firsat eşitliğinin sağlanmasına da katkı sağlamaktadır.

\section{vi) Finansal Hizmetlere Erişimi Artırmaya Yönelik Politikalar}

Kırsal kesimdeki kadınların finansal hizmetlere erişimi genellikle resmi finansal kuruluşlar tarafından geleneksel teminat türleri olarak kabul edilebilecek üretken varlık veya mülklere sahip olmamalarıyla sınırlıdır. Çünkü kadınların mülk veya arazi sahiplenme, yönetme, kontrol etme veya devralma olasılığg erkeklere kıyasla daha düşüktür. Bu teminat eksikliği de kadınların kredi almasını veya diğer finansal hizmetleri kullanmasını zorlaştırmaktadır. Öte yandan kadınlar genellikle kayıt dışı sektörde çalıştıkları ve erkeklerden daha düşük gelir düzeylerine sahip oldukları için resmi finansal sağlayıcılar tarafından potansiyel müşteriler olarak da görülmemektedir. Bu durum aynı zamanda kadınların mülkiyet hakları konusunda yasal ayrımcılığa maruz kaldıkları ülkelerde para biriktirme ve borç alma veya bir banka hesabına sahip olma ihtimallerinin daha düşük olduğunun da bir göstergesi olmaktadır (FAO, 2019: 4-5).

Yoksulluğu azaltmak, paylaşılan refahı artırmak ve sürdürülebilir kalkınmayı teşvik etmek amacıyla oluşturulan Dünya Bankası Grubu (World Bank Group), özellikle kadınlar için finansal içermenin tüm potansiyel faydalarını sağlamak için çalışmaktadır. Dünya Bankası Grubu, kadınlara yönelik cinsiyet eşitliğinin sağlanması ve yoksulluğun azaltılmasına yardımcı olmak amacıyla finansal katılımı teşvik etmektedir. Çünkü kadınlar orantısız bir biçimde ekonomiye katılmalarını ve yaşamlarını iyileştirmelerini engelleyen finansal hizmetlere erişimde birçok problemle karşılaşmaktadır. Kadınlar, kadın girişimciler ve işverenler krediye erişim, banka hesabı açma veya sigorta gibi birçok finansal hizmetlere erişimde erkeklere kıyasla çok daha büyük zorluklarla karşılaşmaktadır. Örneğin bazı ülkelerde kadınlar banka hesabı açabilmeleri için erkek aile üyelerinden birinin iznine tabi tutulmaktadır. Benzer şekilde kadınlar kendi adına bir banka hesabı açabilseler bile bu fonların kullanımına ilişkin karar alma yetkisi genellikle erkek bir akrabaya verilmektedir. Kadınların bu tip engellerle karşılaşmasında, ayrımcılığın yanı sıra finansal eğitim eksikliği de kısitlayıcı bir rol oynamaktadır (World Bank, 2014a).

Global Findex veri tabanına göre, dünya genelinde 515 milyon yetişkinin 2014-2017 yılları arasında bir finans kurumunda veya mobil bir para sağlayıcısı aracılığıyla hesap açtığı görülmektedir. Hesap sayısında artış yaşanmış olsa da kadın ve erkek arasında hâlâ 
eşitsizlikler söz konusudur. 2014-2017 arasında 7 puanlık bir cinsiyet farkı mevcut olup, erkeklerin \%72'si bir banka hesabına sahipken bu oran kadınlarda \%65'tir. Ülkeler açısından bakıldığında ise yüksek gelirli ülkelerde yetişkinlerin \%94'ü finansal bir hesaba sahip iken, gelişen ülkelerde bu oran \%63 olarak kayda geçmiştir. Aynı dönem aralığında gelişen ülkelerdeki cinsiyet fark1 9 puan ile herhangi bir değişiklik göstermemiştir (Demirgüç-Kunt vd., 2018: 4; 10).

Gelişen teknoloji kadınların finansal hizmetlere erişimlerinin önündeki engellerin bazılarının üstesinden gelebilmelerine yardımcı olabilmektedir. Örneğin kadınların otomatik bir işlemle hesaplara başvurmaları veya erişimleri sağlanabilir. Bu bağlamda dijital finansal hizmetler, ödemelerin dijitalleşmesi, kadınlara özel olarak yönlendirilmesi ve kadınların ihtiyaçlarını karşılayacak şekilde tasarlanması, kadınların finansal erişimlerini artırabileceği gibi bu erişimden fayda sağlamasını da beraberinde getirecektir. Dijital finansal hizmetlere erişim, daha geniş bir eşitsizlik bağlamında küçük bir adım gibi görünebilir (IMF, 2019: 25).

\section{C- Kadınların Sosyal Korumaya Erişim Engelleri}

Sosyal koruma tabanlarının kapsayıcı olabilmesi için erişilebilirliği çok önemlidir. Bir programın kapsamının kanunlarca güvence altına alındığı durumlarda bile bazı birey ve gruplar çeşitli nedenlerden dolayı yararlanamamaktadır (UN, 2018: 114). Kadınların sosyal koruma tabanlarına erişimini engelleyen nedenler çok yönlüdür ve programa özgü faktörleri aşmaktadır. Bu engeller genellikle kurumların nasıl tasarlandığını, kamusal alanlarda kadın ve erkeklerin nasıl etkileşimde bulunduğunu ve iş ve kaynakların hane içinde nasıl dağıldığını etkileyen sosyokültürel normlarla bağlantılıdır (Ulrichs, 2016: 21). Bu bağlamda, kadınların sosyal koruma tabanlarına erişim engelleri düşük katkı kapasitesi, farkındalık ve faydaların algılanan değeri, idari prosedürler ve sosyokültürel normlar başlıkları altında ele alınacaktır.

\section{i) Düşük Katkı Kapasitesi}

Sosyal korumanın finansal maliyetleri, istihdamı kayıt altına alma konusunda caydırıcı ve engelleyici olabilmektedir. Bu nedenle sosyal güvenlik, kayıt dışı çalışanlar veya kayıt dışı işletme sahibi olanlar için çok pahalı olabileceğinden uygun olmayabilmektedir. Özellikle düşük ve düzensiz gelir akışları, sübvanse edilen programların yokluğunda kayıt dışı çalışanların sosyal koruma programlarına katkıda bulunma kapasitelerini azaltabilmektedir (Ulrichs, 2016: 21).

Düşük gelir veya düşük katkı kapasitesi, toplumun sağlık sigortası gibi hizmetleri üstlenmesinde çekimser davranmasına neden olabilmektedir. Primli sosyal güvenlik sistemlerinde, sosyal korumanın finansal maliyeti işveren veya çalışanlar için çok pahalı ya da itici gelebilmektedir. Aynı zamanda bu maliyetler, kayıt dışı ve kırsal ekonomi alanlarında da sosyal koruma kapsamı için caydırıcı veya engelleyici bir harekete neden olabilmektedir. Dolayısıyla düşük katkı kapasitesi, kırsal alanlarda sosyal koruma işlevini yerine getiren kurumlara erişimi kısıtlayabilmektedir (Allieu, 2019: 5).

Sosyal koruma programlarının kapsamında standart dışı çalışma biçimleri ve serbest çalışanlara yönelik yasal düzenlemelerin genişletilmesiyle önemli ilerlemeler kaydedilmiş olsa da özellikle serbest çalışanlar, marjinal yarı zamanlı çalışanlar ve geçici çalışanlar için önemli kapsam boşlukları bulunmaktadır. Düşük katkı kapasiteleri, karmaşık idari prosedürler ile yetersiz uyum ve uygulama mekanizmaları, yasal olarak korunmuş olsalar bile bazı işçilerin yardımlardan faydalanmasını engelleyebilmektedir (Behrendt ve Nguyen, 2018: 10). 
Kamu hizmetlerine erişimin ve kalitenin iyileştirilmesi, etkili sosyal koruma programlarının temelini oluşturmaktadır. Kayıt dışı çalışan kadınların sağlık ve çocuk bakımı gibi kaliteli kamu hizmetlerine erişiminin olması, sosyal yardım ve sosyal sigorta programlarının yoksulluğun azaltılması ve toplumsal cinsiyet eşitliği üzerindeki etkisinin önemli oranda artması anlamına gelmektedir. Uzun bekleme süreleri, yüksek kullanıcı ücretleri ve düşük kaliteli hizmetler, genellikle kayıt dışı çalışanların bu hizmetlere erişememelerine neden olmaktadır. Sağlık ve çocuk bakımı maliyetleri, düşük gelirli kayıt dışı çalışanlar için borçlanmaya neden olabilmektedir (WIEGO, 2019: 7).

Ödeme yapmama nedeniyle sağlık sigortasına kayıt yaptıramamak, muhtemelen parasal olarak daha kısıtlı imkanlara ve daha yüksek sağlık harcamalarına sahip kadınları ciddi oranda etkilemektedir. Bu durum, sigorta şirketleri için hamilelik ve doğum sırasındaki bakımı kapsayacak şekilde sağlık sigortası fiyatını önemli ölçüde artıran ve yoksul kadınların dışlanmasına yol açan belirgin bir tehdit oluşturmaktadır. Sağlık sigortası primleri kazanç seviyesine bağlı olduğundan, yoksul işçiler sadece temel sağlık hizmetlerine erişebilirken, yüksek gelirli işçiler özel sağlık şirketlerinden daha kapsamlı programlar satın alabilmektedir. Ayrıca istihdam veya mevsimlik işlerde yapılan kesintiler de işçilerin düzenli ücretlerin ödenmesini gerektiren programlara katkı sağlamak için daha az gelire sahip olduğu anlamına gelmektedir. Dolayısıyla düşük katkı kapasitesi, özellikle kayıt dışı çalışan kadınların temel sosyal koruma tabanlarına erişmelerine engel teşkil etmektedir. Bu engel mutlaka cinsiyete özgü olmasa da çoğunlukla düşük ücretli kayıt dışı istihdamda çalışan kadınları kapsamaktadır. Belli risklerden kadınları korumanın maliyetinin daha yüksek olması nedeniyle hizmet ücretlerinin arttığı yerlerde, program özellikle kadınlara karşı ayrımcılı̆̆a neden olmaktadır (Ulrichs, 2016: 21-22).

\section{ii) Farkındalık ve Faydaların Algılanan Değeri}

Sosyal korumaya erişime engel olan faktörlerden bir diğeri, katılım maliyetiyle ilgili olan faydaların algılanan değerinin yanı sıra programlar hakkında da kısıtlı farkındalığın olmasıdır. Bu, kadınlara özgü bir durum değildir ancak zaman bakımından karşılaştıkları yüksek firsat maliyetleri ve programlara katılmak için sınırlı kaynaklara sahip olmasından dolayı kadınlar için önem arz etmektedir (Ulrichs, 2016: 22). Benzer şekilde kayıt dışı ve kırsal ekonomide çalışanlar, genellikle düşük okuryazarlık ve eğitim seviyesinde ve daha yüksek yoksulluk içerisindedir ve programlarla ilgili bilgiye erişimde daha fazla firsat maliyetiyle karşılaşabilmektedir. Bilgi eksikliği, firsat maliyetlerinin potansiyel avantajlarından daha yüksek olduğunu düşünerek faydalanıcıların programlardan kasıtlı olarak vazgeçmelerine neden olabilmektedir (Allieu, 2019: 5).

Yetersiz bilgi ve farkındalık eksikliği, vaat edilen faydaları sağlamak için sosyal koruma sağlayıcılarına veya hükümetlere duyulan güveni zayıflatabilmekte ve insanların, özellikle katılımın bir maliyetle ilişkilendirilmesi durumunda bu koruma programlarına dahil olmalarını engelleyebilmektedir. Bu hususta bilinci artırmak, iyi yönetişimi sağlamak ve güven oluşturmak özellikle kayıt dışı ekonomide yer alan bireyler ve kadınlara yönelik koruma kapsamını geniş̧letme stratejisi için önem arz etmektedir. Sosyal koruma programları hakkında bilgi ve farkındalık, anahtar unsur olarak görülmektedir. İşçiler ve işverenlerin kendileri için uygun olan programları, haklarını, yükümlülüklerini ve programlardan faydalanabilmek için nasıl erişim sağlayacaklarını bilmeleri gerekmektedir. Bununla birlikte etkili ve kaliteli bir erişim için sadece bilgi yaymak ve bireyleri bilinçlendirmek yeterli olmayıp aynı zamanda güven inşa etmek de eşit öneme sahiptir. İşçi ve işverenler, sosyal korumanın kendileri için değerini tam olarak anlamalı, sosyal koruma sisteminin iyi yönetildiğini ve etkili bir şekilde sunulabileceğini bilmelidir. Bu bağlamda iyi yönetişim ve şeffaflık, işverenlerin karşılaştığı kısıtları göz önünde bulundurarak sosyal koruma 
sistemlerinin işçilerin ihtiyaçlarına cevap vermesini sağlamak için ön koşul kabul edilmektedir. Bir sosyal koruma sistemi, iş̧̧ilerin ve işverenlerin beklentilerini karşılayan faydaları ve hizmetleri iyi bir şekilde sağlarsa etkili ve kaliteli bir erişimin yanında nüfusun güvenine ve desteğine de sahip olacaktır (ILO, 2019b: 54).

\section{iii) İdari Prosedürler}

İdari prosedürler, insanların kaydolma konusunda cesaretlerini kırarak veya katılanları yüksek fırsat maliyetlerine maruz bırakarak, sosyal koruma tabanlarına erişimde engel oluşturabilmektedir. Bu durum, özellikle kayıt dışı çalışanlar için tehlikeli olabilmektedir (Allieu, 2019: 5). Kayıt dışı çalışanlar, genellikle kayıt işlemleri için zaman ayıramamakta, iyi eğitimli olmamalarından dolayı evrak işlerini takip edememektedir. Bu kişiler aynı zamanda ödemelerin yapılacağı veya alınacağı banka hesabına sahip değildir. Benzer şekilde küçük işletmeler de aynı sorunlarla karşı karşıyadır. Bir programın şartları onlar için maliyetli ve zahmetli görülebilmektedir. Kuralları anlamak ve evrak işlerini yürütmek için gereken özel personeli karşılayamamaktadır. Köprü görevi gören vergi danışmanı, danışmanlar ve acenteler gibi aracılar ise az sayıda ve genellikle pahalıdır. Dolayısıyla işverenler, sosyal güvenlik primlerini öderlerse diğer vergileri de ödemek zorunda kalacaklarından ve yönetmeliklere uymaları gerekeceğinden korkup çekimser davranmaktadır (RNSF, 2017: 91).

Kayıt işlemi, bireylerin sosyal koruma programlarına erişim için başvurmuş oldukları noktadır. Programların tüm türlerinde dışlanma, kayıt sürecinin tasarımından kaynaklanmaktadır. Programlara başvurmak isteyen dezavantajlı bireylerin karşılaşmış oldukları en büyük zorluk, özellikle idari yapıların zayıf olduğu ve programlardaki alanların sınırlı olması nedeniyle rekabetin yoğun olduğu durumlarda karmaşık başvuru süreçlerinde gezinmeleridir. Karar vericiler için, sosyal ve siyasi bağları daha zayıf olan bireylerin seçilme ihtimali daha düşüktür. Engellilik veya aşırı yoksulluk içinde yaşama gibi daha büyük kısıtlamalara maruz kalan bireyler için ise bu durum çok daha zor olmaktadır. Karar vericiler tarafından kayıt süresince beklenen rant, bu dezavantajlı bireylerin karşılaşmış olduğu daha da büyük bir engeldir. Örneğin Bangladeş’te aşırı yoksulluk içinde yaşayan ailelerin, ayda sadece 4 dolar yardım alabilmek için karar vericilere 26 dolar ödemeleri gerekmektedir. Bu nedenle rüşvet vermeye gücü yetmeyen bireylerin yaşlılık aylığı için başvuruda bulunamadığı görülmektedir (Kidd, 2017: 226-227).

İdari prosedürler ve sosyal koruma programlarına nasıl kaydolunacağına dair bilgi işçiler için erişilebilir değilse, bu durum gün içerisinde sınırlı zamanı olan kişiler için engel oluşturmaktadır. Bu engeller, katılımın fırsat maliyetinin çok yüksek olabileceği kadın işçilere gelindiğinde çok daha yoğun görülmektedir. Sosyal koruma programlarının özellikle düzensiz ve yardımların geç ödenmesi gibi güvensizliğe neden olan yönetimi, yoksul, anaerkil veya geçimini kadının geliriyle sağlayan haneleri orantısız bir şekilde etkilemektedir. Örneğin Hindistan'da, Mahatma Gandhi Ulusal Kırsal İstihdam Programı (MGNREGS)'ndan yararlanan bazı eşinden boşanmış, ayrılmış veya eşi vefat eden kadınlar ile tek başına yaşayan çocuklu kadınlar geciken ödemelerden etkilenerek bazı durumlarda gelir açığını kapatabilmek için programdan ayrılmak ve tercih edilmeyen istihdam türlerini kabul etmek zorunda kalmışlardır (Ulrichs, 2016: 24).

Sosyal koruma programlarına erişimde karşılaşılan bu tür engellerin aşılabilmesi için karmaşık kayıt sürecinin ve diğer idari prosedürlerin birleştirilmesine yönelik potansiyelin dikkatlice analiz edilmesi gerekmektedir. Daha fazla fiziksel erişim noktası veya teknolojinin potansiyelinden tam olarak yararlanan yenilikçi hizmetler sağlama mekanizması aracılığıyla hizmetlere erişimin kolaylaştırılması bu tarz engellerin aşılmasına yardımcı olabilecektir (ILO, 2019b: 96). 


\section{iv) Sosyokültürel Normlar}

Sosyal normlar, toplumların biçimsel yapılarına, gayri resmi kurallarına, inançlarına ve tutumlarına yansıyan güçlü kurallar topluluğudur. Bu normlar, aynı referans grubuna ait insanlar veya devlet tarafindan empoze edilerek, olumlu veya olumsuz yaptırımlarla güçlendirilmektedir. Sosyal normlar kadınlar, erkekler, kız ve erkek çocuklar için uygun olan davranışları veya beklenen nitelikleri tanımlayarak cinsiyet rollerini oluşturmaktadır. Bireylerin sosyal tutum ve davranışlarının sosyal normlara uygun olması toplumda kabul görmesine ve güvence altına alınmasına katkı sağlarken, sosyal normlara uygun olmayan tutum ve davranışlar sergileyen bireyler olumsuz sosyal yaptırımlara maruz kalabilmektedir (World Bank, 2014b: 15-16). Bu durum, toplumsal cinsiyet algısının ve bireylere atfedilen cinsiyetçi rollerin kadınların çalışma hayatındaki konumunu ve sürekliliğini belirlemede ne kadar etkin bir role sahip olduğunu göstermektedir.

Sosyal koruma programları, doğrudan kadınlar veya bireyler yerine hanehalkını hedef alacak şekilde tasarlandığında, kadınların programlara erişimini ve üretim kaynakları üzerindeki kontrolünü etkileyen hanehalkı içindeki güç dinamiklerinin eşitsizliğini dikkate almamaktadır. Tüketimdeki bu cinsiyet boşlukları göz ardı edildiğinde, sosyal koruma programları yoksul olmayan bir hanede yaşayan yoksul kadınları dikkate alma konusunda başarısız olmaktadır. Kadınların erişimini etkileyen sosyokültürel normları dikkate almadan tasarlanan programlar, kadınların bazı sosyal haklardan yararlanmalarını engelleyebilmektedir. Örneğin, kadınların hanehalkı dışındaki hareketliliğini kısıtlayan sosyal normlar, onlara ödemelerin yapılmasını engelleyebilmektedir. Benzer şekilde çocuk bakım hizmetlerinin eksik veya yetersiz olması, kamu istihdam programlarından yararlanmalarını olumsuz yönde etkileyebilmekte ve katılımlarını engelleyebilmektedir (UN, 2018: 19).

Kadınlar, çalışma hayatında çeşitli zorluklarla karşılaşmaktadır. Erkekler ile farklı okuryazarlık ve beceri seviyesine sahip olan kadınlar, miras ve toprak mülkiyeti gibi ayrımc1 yasaları da içeren ve hanehalkı içinde pazarlık gücünün düşük olmasına neden olan sosyokültürel normların bir sonucu olarak hem ücretli işlere erişmede hem de üretim için ihtiyaç duydukları kaynaklara ulaşmada engellere takılmaktadır (Holmes vd., 2011: 257). Öte yandan sosyokültürel normlar kadınların siyasi alanlara katılımı ve erişimini de engelleyebilmektedir. Sosyal normlar, genellikle erkeklerin kadınlardan daha iyi lider olabileceği fikrini güçlendirmekte, kadınların siyasi ve kamusal rollerde temsil edilme isteğini sınırlamaktadır (World Bank, 2018: 162).

\section{D- Kadınlara Yönelik Ulusal Sosyal Koruma Tabanlarının Güçlendirilmesine Yönelik Stratejiler}

Sosyal koruma, yoksulluk ve eşitsizlikle mücadele etmek, insanların refahını artırmak ve sosyal içermeyi kolaylaştırmak için gereken politika araçlarından biridir. Bu bağlamda sosyal koruma, riski önlemeyi, yönetmeyi ve üstesinden gelmeyi amaçlamaktadır. Gelişen ülkelerde kadınların günlük yaşamlarında karşılaştıkları riskler, biyolojik özelliklerde ve sosyal normlarda erkeklerden farklılık göstermekte ve yaşam döngüsü üzerinde farklılaşarak şekillenmektedir. $\mathrm{Bu}$ farklılıklar, erkeklere yönelik tasarlanan programların özelliklerinin kadınlara uygun olmadığı anlamına gelmektedir. Dolayısıyla sosyal korumaya erişimde eşitlik, kadınların çalışmasının farklı doğasını ve karşılaştıkları farklı riskleri yansıtan programları gerektirmektedir. Kapsamlı ve hak temelli sosyal koruma sistemlerinin sosyal bölünmeleri azalttığı ülkelerde bile dışlanma ve ayrımcılık tam anlamıyla giderilememekte ve programlar tek başlarına dışlanmanın tüm belirtileri ve itici gücüyle baş edememektedir. Ayrımcılık da dahil olmak üzere dışlanmanın temel nedenlerini ele almak ve eşitliği 
sağlamak, geniş bir ekonomik ve sosyal politika kümesi gerektirmektedir (UN, 2018: 112; Cameron, 2019: 3).

Sosyal koruma tabanı uygulamak, hükümetin mevcut sistemlerinin güçlü-zayıf yönlerini analiz etmek ve sağlık hizmetlerini sosyal politikasının merkezine koymak için büyük bir çaba sarf etmesine neden olacaktır. Buradaki temel düşünce, sosyal koruma tabanının yoksullukla mücadelenin bir yolu olmasının yanı sıra refahın kötüye kullanılmasını önleyerek, sosyoekonomik ve cinsiyet eşitsizliği ile mücadele etmede bir araç olarak kullanılması gerekliliğidir. Mevcut programlar, sosyal koruma tabanı kapsamındaki garantileri hem yatay (daha fazla insan) hem de dikey (daha fazla fayda) olarak genişletecek şekilde inşa edilmelidir. Bununla birlikte, maliye politikalarının da yeterli düzeyde bir gelir güvencesi sağlayabilmesi ve sosyal koruma tabanlarını finanse edebilmesi için artan oranda gelişim ve ilerleme göstermesi gerekmektedir (UNDP-ILO, 2012: 27-28).

Düşük üretkenlik ve yoksulluk tuzaklarıyla birlikte kayıt dışılığın sosyal ve ekonomik maliyeti, kayıt dışılık oranının yüksek olduğu ülkeler için temel kalkınma problemlerinden birini oluşturmaktadır. Bu nedenle son yıllarda birçok ülke kayıt dışı istihdama önem vererek eşitsizliği, yoksulluğu ve savunmasızlığı azaltmada bir strateji olarak kayıt dışı ekonomideki bireyler için sosyal korumaya geçiş yollarını aramıştır. Sosyal koruma, özellikle savunmasız çalışanlar için çalışma süreleri boyunca ve sonrasında karşılaşabilecekleri risklerden korunmalarında etkili rol oynamaktadır. Bu bağlamda ülkeler, politika reformu aracılığıyla hem kayıt dışı ekonomide yer alan işçilerin sosyal koruma kapsamını genişletmek hem de kayıt dışı çalışan kadınların sosyal güvenliğe erişimde karşılaştıkları somut engelleri azaltmak için çalışmalar yapmıştır (Ulrich, 2016: 27).

Kadınlar arasında gelir ve zaman yoksulluğunu azaltmak için kamu kaynakları etkin kullanılmalıdır. Kamu kaynaklarını artırmak, bu hedef ve stratejilere uyum sağlamak ve aynı zamanda kamu harcamalarını artırmak ve takibini yapmak için bir strateji bileşimi gerekmektedir. Gelişen ülkelerin çoğunda, sosyal harcamaları artırmak amacıyla kamu kaynaklarını harekete geçiren önemli bir faaliyet alanı bulunmaktadır. Örneğin, 17 Latin Amerika ülkesinden elde edilen verilere göre, GSYİH içerisindeki sosyal harcamaların oranı 2000 yılında ortalama \%8,5 iken, 2016'da bu oran \%11,2'ye yükselmiştir. Bu ülkelerde sosyal politikalar için bu yüksek finansman seviyeleri eğitim, sağlık ve sosyal korumaya daha fazla yatırım yapılmasını içermektedir. Sosyal harcamalara yönelik bu tür artışlar vergi toplama yönetiminin iyileştirilmesi, vergi sistemi yapısının düzeltilmesi, vergi tabanını çeşitlendirmek için yeni vergilerin getirilmesi ile doğal kaynaklardan gelir akışının artırılması ve borç ödeme şeklinin değiştirilmesini içeren bir dizi strateji aracılığıyla elde edilebilmektedir (UN General Assembly Resolution, 17.06.2019, A/74/111).

Birçok ülke, kayıt dışı istihdamda yer alan kadınların kapsamını iyileştirmek için resmi sosyal güvenlik programlarının dışında yer alan yeni programlar getirmiştir. Benzer şekilde farklı ülkelerde, savunmasız gruplara yönelik sosyal yardım programlarının artmasının yanında, sosyal korumadan yararlanmayan ve yüksek düzeyde kayıt dışı çalışanlara yönelik primsiz sosyal güvenlik uygulamaları yaygınlaşmıştır. Birçok ülkede resmi sosyal güvenliğe erişemeyen kadınlara yönelik analık yardımı sağlayan programlar uygulanmaktadır. Örneğin, 2008 yılında Bangladeş’te yoksul emziren annelere yönelik iki yıl süre ile birinci veya ikinci hamileliği için her ay belli bir miktarda ödenek sağlayan "Annelik Ödeneği Programı" uygulanmaya başlamıştır. Hindistan'da ise 2010 yılında başlatılan bir program ile 52 pilot ilçede hamile kadınlar ile emziren annelere yaklaşık 40 gün boyunca ücret kaybının kısmi tazminatı olarak nakit yardımlar yapılmakta, aynı zamanda doğum öncesi ve sonrası için yeterli dinlenme imkânı sağlanmaktadır (Ulrich, 2016: 29-30). 
Kadınların sosyal koruma tabanlarına erişimdeki dezavantajlarının üstesinden gelmek, kadınların farklı durumlarına uyum sağlamayı gerektirmektedir. Devletler, kadınlara yönelik uyarlanmış programları tasarlayabileceği gibi, sivil toplum kuruluşları (STK) da kadınlara ulaşmada özellikle etkili olabilmektedir. STK'lar hem az temsil edilen grupları kapsayarak hem de düşük kaliteli veya yetersiz hükümet programlarına alternatifler sunarak, devlet tarafından sağlanan sosyal korumadaki boşlukları doldurabilmektedir. Ayrıca bilgilendirme kampanyaları, yönlendirme hizmetleri ve resmi sosyal koruma programlarına katılabilmeleri için gerekli olan dokümantasyonu alabilmelerinde kadınlara yardımcı olarak, devlet programlarına erişimlerini de kolaylaştırabilmektedir (Cameron, 2019: 4).

Sosyal koruma programlarının özellikle kadınlar gibi dezavantajlı gruplara yönelik daha güçlü, kapsayıcı ve erişilebilir olmasında evrensellik önemlidir. Koşulsuz herkes için uygun olan evrensel sosyal koruma programları hem çok daha fazla kapsayıcı hem de ihtiyacı olan kişilere karşı ayrımcılık olasılığı çok daha düşüktür. Ayrıca programdan faydalananların damgalanma riski daha azdır. Fakat yine de sosyal koruma programları evrenselcilik temelli bir politika kapsamında olsa dahi nüfusun bazı kesimleri yoksulluk ve sosyal dışlanmaya maruz kalmakta ve bunun üstesinden gelmede daha büyük zorluklarla karşılaşmaktadır. $\mathrm{Bu}$ hususta, sadece geçici bir çözüm olsa da tamamlayıcı özel veya farklılaştırılmış önlemler, bu kesimin karşılaşmış olduğu zorluklarla mücadele edebilmelerinde ve evrensel kapsamın sağlanabilmesinde gerekli olabilmektedir. Örneğin sosyal bakım hizmeti bileşenleri tarafından tamamlanan engellilik yardımları, dışlanan gruplar için erişimi geliştirmek amacıyla kullanılmaktadır. Ancak özel önlemler maliyetli olabilmektedir. Özel desteğe ihtiyaç duyabilecek kişileri belirlemek ve onların ihtiyaçlarını anlayabilmek için güçlü bir idari kapasite gerekmektedir. Bu hususta, sosyal koruma kurumlarının kapasitelerinin artırılmasına yönelik özel önlemler önemli görülmektedir. Ancak bu durum harcamaları azaltmak için bir araç olarak kullanılmamalıdır. Sosyal haklar ve iletişim kampanyaları faydalanıcıları haklarından haberdar etme konusunda erişimi iyileştirebileceği gibi, hükümetler de özel önlemlerin daha geniş sosyal koruma sistemlerine iyi bir şekilde entegre edilmesini sağlamalıdır (UN, 2018: 114-115).

Kadınların daha etkin ve etkili biçimde sosyal korumadan faydalanmasında teknolojinin gücünden ve dijital finanstan yararlanmanın önemli bir etkisi olacağı düşünülmektedir. Finansın dijitalleşmesi, cinsiyet eşitliğine doğru ilerlemeyi engelleyen zorlayıcı ve çoğunlukla sistemik, sosyal, ekonomik ve çevresel sorunlara çözümler getirebilmek için sosyal süreci ve gelişimi desteklemelidir. Dijital finansta cinsiyete duyarlı bir yaklaşımın benimsenmesi, dijitalleşme ve uygun risk azaltma eylemlerini açıklamak için cinsiyete özgü farklı kırılganlıkların tespitine yardımcı olacaktır. Böylece mevcut cinsiyet açı̆̆ının kapatılmasına da olumu bir etkisi olacaktır. Ayrıca kadınlara ve kız çocuklarına, yaşamlarını ve toplumlarındaki insanları etkileyecek dijital finans hizmetlerini ve politikalarını şekillendirecek yenilikçiler ve etkileyiciler olmaları için eşit haklar ve fırsatlar sunacaktır (Molinier ve Quan, 2019: 20).

Evrensel sosyal koruma programlarının güçlü kurumlar tarafindan desteklenmesi, kapsayıcılığı ve erişilebilirliği açısından önemlidir. 2030 gündeminde yer alan etkili, hesap verebilir ve şeffaf kurumları teşvik etme çağrısı, bu programların başarılı olmasının anahtarı görülmektedir. Kapasite ve kurumsal eksikliklerin varlığı, programların etkinliğini baltalamakta ve birçok düşük gelirli ülkede programların hedeflediği ihtiyaç sahiplerine veya faydalanıcılara ulaşılmasını kısıtlamaktadır. Sosyal korumanın kapsayıcı biçimde uygulanabilmesi için kurumsal çerçevenin belli koşulları yerine getirmesi gerekmektedir. Burada kapsayıcı ve etkili bir sosyal koruma için yapılacak olan düzenlemeler, ülke bağlamına göre değişiklik gösterse de genellikle güçlü bir koordinasyon gerekmektedir. Bir diğer önemli husus ise, karmaşık ve uzun idari prosedürleri basitleştirerek, evrak işlerini 
azaltmak ve çakışan sistemlerden kaçınmak gibi düzenlemelerdir. Çünkü ileri seviyede okuryazarlık ve çokça zaman gerektiren prosedürler, en çok desteğe ihtiyacı olan kesimi dışlama eğilimindedir. Bir diğer önemli husus da herkes için yasal kimlik sağlayan güçlü bir sivil kayıt sisteminin oluşturulması gerekliliğidir. Böylece uzak kırsal alanlarda ve yüksek riskli kentsel alanlardaki insanlara erişim sağlanmalıdır. Ayrıca insanlar kendileri için uygun olan programlar hakkında bilgilendirilmelidir. Benzer şekilde, resmi dili akıcı bir şekilde konuşamayan yerli insanlar veya göçmenler, program hakkında az bilgi sahibi olanlar veya engelli kişilerin kendilerini dışlanmış hissetmemeleri için kişilerin ihtiyaçlarına göre uyarlanmış bilgilendirme kampanyaları ile sosyal koruma programları çok daha kapsayıcı hale getirilebilmektedir (UN, 2018: 116-117).

\section{SONUÇ}

Sosyal koruma sistemi; sosyal sigortalar, sosyal yardım ve hizmetleri kapsayarak özellikle kadınlar gibi dezavantajlı gruplara asgari bir gelir güvencesi ve temel hizmetlere erişim sağlayan, yoksulluğu ve kırılganlığı azaltan, insan sermayesini geliştirerek istihdam olanakları sunan bir dizi politika ve program setini ifade etmektedir. Bu kapsamda bireylere hastalık, analık, yaşlılık ve işsizlik gibi temel risk alanlarında güvence sağlanmasının yanında yoksulluğu ve kırılganlığ 1 azaltma, eşitsizliği önleme ve insan onuruna yaraşır biçimde yaşama gibi amaçlar doğrultusunda nakdi veya ayni yardım ve hizmetler sunulmaktadır. Uygulanan tüm bu politikalar, yardım ve hizmetler kadınların çalışma hayatına katılımında ve sürekliliğinin sağlanmasında olumlu etkilere sahiptir. Ayrıca bu programlar kadınların güçlendirilmesi, toplumsal cinsiyet eşitliğinin sağlanması ve kadınlar gibi dezavantajlı grupların sosyal dışlanmasının önlenmesine de katkı sağlamaktadır. Bu bağlamda sosyal koruma programları kadınlar açısından ayrı bir önem arz etmekle birlikte kapsayıcılığı ve ekonomik büyümeyi teşvik etmesi, sosyal uyumu ve bütünlüğü sağlaması ve politik istikrarı artırması bakımından ülke ve toplum refahı üzerinde de kayda değer etkilere sahiptir.

Öte yandan, sosyal koruma programlarının finansal maliyetleri, düşük katkı kapasitesi, idari prosedürlerin karmaşıklığı ve programlara yönelik farkındalığın ve bilginin yetersizliği gibi olumsuz faktörlerin, kadınların bu programlara erişimlerini engellediği gözlemlenmektedir. Ayrıca, kadınların sosyal koruma programlarına erişimlerindeki bir diğer ve en önemli engelin sosyokültürel normlar çerçevesinde toplumun kadına atfettiği roller ve tutumlar olduğu görülmektedir. Günümüzde halen kadınlar, toplumsal cinsiyet rollerinin bir sonucu olarak aile içi sorumluluğunun önemli bir kısmının kadına yüklenmesi, kadın istihdamının artmasına rağmen yalnızca belli mesleklerle sınırlı kalması ve eğitim seviyesinin yetersizliği gibi nedenlerle çalışma hayatının dışında kalmaya devam etmektedir. İstihdam içerisindeki kadınların oranı ise ne yazık ki istenilen seviyeye ulaşamamıştır. Gelinen bu noktada, sosyal koruma uygulamalarının belirlenen hedeflere ulaşabilmesi ve tam bir koruma sağlayabilmesi hususunda programların doğrudan kadınların ihtiyaçlarını, sosyokültürel normları ve programlara erişimde karşılaştıkları engelleri dikkate alarak tasarlanması şüphesiz etkili olacaktır. Bu bağlamda, programların kadın ve erkeklerin karşılaşmış oldukları farklı yoksulluk ve kırılganlık deneyimlerini dikkate alarak ve cinsiyete duyarlı bir yaklaşım çerçevesinde tasarlanması ve uygulanması, çok daha kapsayıcı ve etkili bir koruma sağlayacaktır. Bununla birlikte, programların karmaşık ve uzun idari prosedürlerinin daha basit hale getirilmesi, şeffaf ve anlaşılır olması da programların erişilebilirliğini ve etkinliğini artıracaktır. Ayrıca, sosyal koruma programlarında evrensellik de oldukça önem arz etmektedir. Herkes için uygun, kapsayıcı ve erişilebilir evrensel programlar, ihtiyaç duyan tüm bireylere koruma sağlayabilir ve ayrımcılık olasılığının çok daha düşük olmasına katkıda bulunabilir. 


\section{Kaynakça}

Allieu, A. M. (2019). Implementing Nationally Appropriate Social Protection Systems and Measures for All: Gaps and Challenges Facing Rural Area. A Presentation at the UN DESA Expert Group Meeting on Eradicating Rural Poverty to Implement the 2030 Agenda for Sustainable Development. [https://www.un.org/ development/desa/dspd/wpcontent/uploads/sites /22/2019/03/Andrew-Allieu_SP-for-rural-areas _22-Feb-18.pdf]. (Erişim: 25 Kasım 2019).

Arnold, C., Convey, T. ve Greenslade, M. (2011). Cash Transfers Literature Review. DFID Department for International Development April 2011.

Aykaç, M. ve Murat, G. (2018). Sürdürülebilir Kalkınma Gündemi Bağlamında Çocuk İşçiliğinin Önlenmesinde Sosyal Koruma Tabanları. Uluslararası Yönetim Iktisat ve İşletme Dergisi. CEEİK 2018 Özel Sayısı. 93118.

Behrendt, C. ve Nguyen, Q. A. (2018). Innovative Approaches for Ensuring Universal Social Protection fort he Future of Work. ILO Future of Work Research Paper Series. Geneva.

Beleza, M. L. (2003). Discrimination Against Women with Disabilities. Germany: Council of Europe Publishing.

Browne, E. (2015). Social Protection: Topic Guide. UK: GSDRC. University of Birmingham. Birmingham.

Cameron, L. A. (2019). Social Protection Programs for Women in Developing Countries. IZA World of Labor 2019. 14(2). 1-10.

Demirgüç-Kunt, A., Klapper, L., Singer, D., Ansar, S. ve Hess, J. (2018). The Global Findex Database 2017: Measuring Financial Inclusion and the Fintech Revolution. Washington DC: World Bank Publications.

ESCAP (2015). Time for Equality: The Role of Social Protection in Reducing Inequality in Asia and the Pacific. [https://www.unescap.org/sites/ default/files/SDD\%20Time\%20for\%20Equality \%20report_final.pdf].(Erişim: 28 Ekim 2019).

ESCAP (2018). Why We Need Social Protection. [https://www.socialprotectiontoolbox.org/files/docu ments/Social-Protection-module1.pdf]. (Erişim: 28 Ekim 2019).
European Commission (2018). The 2018 Pension Adequacy Report: Current and Future Income Adequacy in Old Age in the EU. European Commission Directorate-General for Employement, Social Affairs and Inclusion. Belgium.

FAO (2019). Women's Access to Rural Finance: Challenges and Opportunities. Food and Agriculture Organization of the United Nations. Rome.

Holmes, R. ve Scott, L. (2016). Extending Social Insurance to Informal Workers: A Gender Analysis. ODI Working Paper March. 2016. London: ODI.

Holmes, R., Jones, N., Mannan F., Vargas, R., Tafere, Y. ve Woldehanna, T. (2011). Addressing Gendered Risks and Vulnerabilities Through Social Protection: Eexamples of Good Practice from Bangladesh. Ethiopia, and Peru. Gender \& Development. 19(2). 255-270. doi: 10.1080/13552074.2011.592637.

[https:// socialprotection-humanrights.org/keyissues/social-protectionsystems/unemploymentprotection/]. (Erişim: 29 Ekim 2019).

[https : / / socialprotection-humanrights.org/keyissues / social - protection-systems/disabilitybenefits/.] (Erişim: 29 Ekim 2019).

ILO (2015). Social Protection for Maternity: Key Policy Trends and Statistics. International Labour Office Social Protection Department. Geneva.

ILO (2017a). World Social Protection Report (2017-19). Universal Social Protection to Achieve the Sustainable Development Goals. International Labour Office. Geneva.

ILO (2017b). World Employment and Social Outlook: Trends for women 2017. International Labour Office. Geneva.

ILO (2019a). A Quantum Leap for Gender Equality: for a Better Future of Work for All. International Labour Office. Geneva.

ILO (2019b). Extending Social Security to Workers in the Informal Economy: Lessons from International Experience. [https://www. usp2030.org/gimi/RessourcePDF.action;jsessio nid=px0ebeLgPN5z3xjN7LX4_XbXPqHnwUU AipRkqtZkoVd K4BMieNL!2052637978?id= 55728]. (Erişim: 30 Kasım 2019). 
IMF (2019). Finance and Development: Women and Growth. A Quarterly Publication of the International Monetary Fund March 2019. 56(1).

Kidd, S. (2017). Social Exclusion and Access to Social Protection Schemes. Journal of Development Effectiveness. 9(2). 212-244. doi: 10.1080/19439342.2017.1305982.

Low, H. ve Pistaferri, L. (2010). Disability Risk. Disability Insurance and Life Cycle Behavior. National Bureau of Economic Research. No. w15962.

Molinier, H. ve Quan, A. (2019). Leveraging Digital Finance for Gender Equality and Women's Empowerment. the Innovation Facility of the UN Women Headquarters September 2019. New York.

Murat, G. (2019). Küreselleşme ve Sosyal Politikaya Yansımaları. Küreselleşme Sürecinde Türkiye'de Sosyal Politikalar. (Editörler: Mustafa Şen, Güven Murat). Bursa: Ekin Yayınevi. 1-58.

Norton, A., Conway, T. ve Foster, M. (2001). Social Protection Concepts and Approaches: Implications for Policy and Practice in International Development. Overseas Development Institute Working Paper 143. February 2001. London.

OECD (2008). Gender and Sustainable Development: Maximising the Economic. Social and Environmental Role of Women. [https://www.oecd.org/social/40881538.pdf].

(Erişim: 02 Kasım 2019).

Ortiz, I. ve Juergens, F. (2019). Social Protection for Older Women. AARP International: The Journal. Vol. 12. 28-31. doi: https://doi.org/10.26419/int.00036.007.

RNSF (2017). Extending Coverage: Social Protection and the Informal EconomyExperiences and Ideas from Researchers and Practitioners. Research. Network and Support Facility. ARS Progetti. Rome; Lattanzio Advisory. Milan; and AGRER. Brussels.

Schmieder, J. F. ve Wachter, T. V. (2016). The Effects of Unemployment Insurance Benefits: New Evidence and Interpretation. Annual Review of Economics. 8(1). 547-581.

Social Protetion Floors Recommendation (2012). International Labour Organization. R202. (14 Haziran 2012).
Ulrichs, M. (2016). Informality, Women and Social Protection: Identifying Barriers to Provide Effective Coverage. ODI Working Paper April 2016. London: ODI.

UN (2018). Promoting Inclusion throug Social Protection: Report on the World Social Situation 2018. Department of Economic and Social Affairs. New York.

UN General Assembly Resoluiton. 17.06.2019. A/74/111. [ https : / / www . unwomen . org / en/ digitallibrary/publications/2019/06/worldsurvey-on-the-role-of-women-indevelopment2019]. (Erişim: 28 Kasım 2019).

UNDP-ILO (2012). Fighting Inequality from The Basic: The Social Protection Floor and Gender Equality. Publications of the International Labour Office. The United Nations Entity for Gender Equality and the Empowerment of Women and UNDP. El Salvador.

UNFPA (2018). Young Persons with Disabilities: Global Study on Ending GenderBased Violence and Realising Sexual and Reproductive Health and Rights. [https://www.unfpa.org/sites/default/files/pubpdf/Final_Global_Study_English_3_Oct.pdf]. (Erişim: 04 Kasım 2019).

Wheeler, R. S. ve Kabeer, N. (2005). Gender Equality and Extension of Social Protection. ESS Paper no. 16. International Labour Office. Geneva.

WIEGO (2019). Extending Social Protection to Informal Workers. [https://www.wiego.org/sites/ default/files/migrated/publications/files/Social \%20Protection\%20Informal\%20Workers\%20f or\%20web_0.pdf]. (Erişim: 25 Ekim 2019).

World Bank (2014a). Expanding Women's Access to Financial Services. [https://www. worldbank. org/en/results/2013/04/01/bankingon - women - extending - womens - Access to-financial-services]. (Erişim: 19 Kasım 2019).

World Bank (2014b). Voice and Agency: Empowering Women and Girls for Shared Prosperity. [https://www.worldbank.org/content /dam/Worldbank/document/Gender/Voice_and agency_LOWRES.pdf]. (Erişim: 26 Kasım 2019).

World Bank (2018). Turkey’s Integrated Social Assistance System (English). [http:// documents.worldbank.org/curated/en/51523153 0005107572 / Turkey - s - integrated - social assistance-system]. (Erişim: 22 Ocak 2020). 